UDC 81'1:929 Belić A.

https://doi.org/10.18485/ms_zmss.2021.99.24

\author{
Дарко Илин \\ Fakulteta za humanistiko Univerze v Novi Gorici \\ Филолошки факултет Универзитета у Београду \\ darko.ilin@yandex.com \\ Darko Ilin \\ School of Humanities University of Nova Gorica \\ Faculty of Philology University of Belgrade \\ darko.ilin@yandex.com
}

\title{
ПОГЛЕДИ АЛЕКСАНДРА БЕЛИЋА НА ПИТАҢА О СЛОВЕНАЧКОМ ЈЕЗИКУ
}

\author{
ALEKSANDAR BELIĆ'S VIEWS \\ ON THE ISSUES OF SLOVENE LANGUAGE
}

У овом раду се у разматрају искази из различитих научних и популарних дела Александра Белића, који се посредно или непосредно тичу словеначког језика и његовог односа према српском или српскохрватском језику. Ако се има у виду висок положај Александра Белића у хијерархији југословенског културног и лингвистичког система, његови погледи на питања о словеначком језику анализирани су кроз призму језичке политике. У првом делу рада ће фокус бити на питању развоја Белићеве мисли о припадности кајкавског наречја словеначком или српскохрватском језичком дијасистему. Други део рада посвећен је Белићевим ставовима о словеначком језику у контексту југословенског уједињења. Овакав приступ ће омогућити да се осветли положај словеначког језика у оквиру прве југословенске државне заједнице.

Кључне речи: словеначки језик, Александар Белић, језичка политика, кајкавско наречје, југословенско уједињење.

This article analyzes Aleksandar Belić's statements from his various scientific and popular works, which directly or indirectly concern Slovene language and it's relationship towards Serbian or Serbocroatian language. Considering Aleksandar Belić's high position in the hierarchy of the Yugoslav cultural and linguistic system, his views on the issues of Slovene language will be analyzed through the lens of language policy. The focus of the first part of the article will be on the issue of the development of Belić's thought on Kajkavian regiolect and whether it belongs to the Slovene or to the Serbocroatian linguistic diasystem. The second part of the article will be dedicated to Belić's views on the Slovene language in the context of the Yugoslav unification. This approach will allow us to elucidate the position of the Slovene language within the first Yugoslav state union.

Key words: Slovene language, Aleksandar Belić, language policy, Kajkavian, Yugoslav unification. 


\section{Увод или границе мога језика}

Језичко питање на подручју бивше Југославије представља веома велики извор не само лингвистичких већ и политичких, културних, социолошких, економских и многих других недоумица. Како је на овим подручјима живело, и још увек живи, мноштво народа (и народности), од великог је значаја осврнути се на начине на које су у предјугословенском, југословенском и постјугословенском контексту језици као такви настајали и себи обезбеђивали лингвистички, а самим тим и културни, те политички престиж. У југословенском случају важно је имати у виду време јављања и јачања југословенске идеје и југославизма међу Јужним Словенима, као и културни контекст романтизма, који је донео ново схватање нације и снажан обрт према народном језику. Нације су, наиме, током романтизма биле дефинисане као скупине људи које здружује јединствен заједнички и засебан језик; то што се један идиом могао класификовати као језик значило је да његови говорници чине нацију, а такво схватање обликовало је многе националне покрете у деветнаестом веку (Leersen 2013: 12). Стога је у том контексту потребно сагледавати настојања илирског покрета и потписивање бечког Књижевног договора, не пренебрегавајући при томе специфичан положај и статус јужнословенских народа унутар других наднационалних творевина. Наиме, остваривањем лингвистичког, а самим тим и националног заједништва, јужнословенски народи имали би већу моћ самоодређења у оквирима тадашњег геополитичког система.

Након Првог светског рата настаје Краљевина Срба, Хрвата и Словенаца, која представља први вид целовите реализације југословенске идеје, а централно место у тој државној заједници имали су Срби и Хрвати, као две најбројније и културно надмоћније етничке заједнице. Питању односа српскохрватског и словеначког језика у међуратном периоду није посвећено довољно научне пажње, што посебно изненађује ако се има у виду да је званични језик Краљевине Срба, Хрвата и Словенаца носио назив српско-хрватско-словеначки 1 . Тако је, на пример, у сенци знамените Скерлићеве „Анкете о јужном или источном наречју у српско-хрватској књижевности“ из 1913. године, остала „Anketa o jugoslovanskem vprašanju“, која је исте године била објављена у часопису Veda, а која је постављала питање о могућности одбацивања словеначког у корист заједничког српскохрватског језика као јединог званичног у будућој државној заједници.

1 Словеначки језик први пут је уставно одређен као званични језик још у Видовданском уставу, међутим, он је у том својству споменут не као независан и засебан језик, већ као повезан са остала два језика (Novak Lukanovič 2007: 188). Оваква ситуација одсликава веома компликован формални статус словеначког језика у систему предратне Краљевине Југославије. 
Узимајући све поменуто у обзир, ваљало би однос српскохрватског и словеначког језика сагледати у светлу језичке политике повезане са изградњом нације. Наиме, национални језик има неколико веома важних улога у процесу изградње нације, попут утилитарне, која омогућава функционисање политичког и економског живота, кохезивне, која омогућава нацији да развије културу заједничку свим припадницима, и диференцијалне улоге, која обезбеђује легитимитет нацији као ентитету који се разликује од других нација (Wright 2016: 47). Стога се питања језичке политике и језичког планирања управо у преломном времену формирања и трајања прве државне заједнице Јужних Словена мора посматрати као идеолошко питање. Поврх тога, у односу српскохрватског као већег и словеначког језика као суседног и мањег уочавају се обриси хијерархизације која, упркос званичној равноправности трију језика у његовом уставном имену, одсликава како идеолошку тако кохезивну и утилитарну функцију једног националног језика. Дискурс доминације и хијерархизације може се тако ишчитати у одговора ${ }^{2}$ Милана Решетара на словеначку „Anketu o jugoslovanskem vprašanju“, односно, из његовог става о императиву да српскохрватски преузме улогу јединог књижевног језика, те његовог непристајања на компромисе у вези са стварањем новог вештачког идиома као мешавине обају језика, као и на компромис о изопштавању турцизама из српскохрватског језика (1913: 378-379), из чега се очитује да су језичку ситуацију у време стварања заједничке државе Јужних Словена одликовале „тензије у лингвистичком простору“ (Liddicoat 2014).

Пошто се зна да је барем у школској пракси „словеначки језик био признат као засебан језик, али очигледно није био једнак српскохрватском“" (Troch 2010: 164), потребно је осврнути се на то како су инстанце лингвистичке и културне моћи са привилеговане позиције посматрале питање словеначког језика у Краљевини. Стога је важно посветити пажњу најзначајнијој личности српске науке о језику прве половине XX столећа, Александру Белићу и његовим ставовима у вези са питањима о словеначком језику, а који се могу разматрати у оквирима социолингвистике.

Александар Белић обележио је развој српске лингвистике прве половине XX века, а био је продуктиван и након Другог светског рата. Његова дела представљају незаобилазан темељ српске филологије и лингвистике, а од посебне је важности његов рад на осветљавању историје српског језика. Међутим, његов културни ангажман је такође оставио значајан траг у српској историји, на пример, у образлагању ратних циљева Србије и захтева за уједињењем југословенских земаља насељених

2 Ово не представља једини, већ један од многих примера унитаристичке језичке политике, која је подразумевала апсолутизацију српскохрватског језика као јединог званичног језика на штету словеначког. У том контексту значајно би било поменути и чланак „Питање југословенског књижевног језика и Словенци“ етнолога Петра Булата, који се залагао за „тиху ликвидацију“ словеначког језика (Bulat 1932: 755), као и књигу Наца кулитурна оријенйација у gанащъюј Евройи Владимира Дворниковића. 
Србима, Хрватима и Словенцима, а које су до тада биле у саставу Аустроугарске (Стевановић 2018: 73). Културни рад Александра Белића стога омогућава да се његово лингвистичко дело сагледа у културолошком контексту, ако се има у виду да он представља доминантни ауторитет на две равни: он долази са српскохрватског језичког подручја које је у датом историјском тренутку било надређено словеначком језичком систему, а са друге стране, његов друштвени углед професора, а касније и ректора Универзитета у Београду, као и председника Српске краљевске академије, омогућио му је да се нађе на позицији моћи високо у хијерархији читаве југословенске културе. М. Ђукановић (2019: 139) у том контексту тврди да је Александар Белић кроз своју богату научну каријеру посредно или непосредно на много начина утицао на развој словенистике. Овај рад ће се фокусирати на два аспекта Белићевог дела у вези са словеначким језиком, и то на однос хрватског кајкавског наречја и словеначког језика, те на Белићеве ставове о словеначком језику и култури у контексту стварања јединствене југословенске културне и језичке реалности.

\section{Питање кајкавског наречја и његове припадности}

Имајући у виду компликован положај словеначког језика и његових дијалеката, који заједно чине један лингвистички разуђен систем, Александар Белић је записао „да се може слободно тврдити да нема ниједног словенског народа код којега би на тако малом простору владало толико диалекатско шаренило као у Словенаца и да нема ниједног словенског језика којим се човек могао у научним истраживањима тако тешко користити као материалом словеначких говора, иако нам је приличан део њихов био познат“ (Белић 1924: 239). У том контексту најсложенији је однос између словеначког језика и кајкавског наречја које улази у састав хрватског језика. Овај је однос на различите начине тумачен, те је тако у историји словенске лингвистике и филологије могуће пронаћи разноврсна објашњења датог односа.

Сажимајући начине на које су знаменити слависти поимали однос словеначког језика и кајкавског наречја, Марко Зајц тврди да је Добровски сматрао словеначки језик верзијом хрватскога, односно целину словеначког и хрватског кајкавског разумевао је као једну етничку целину под хрватским именом (2006: 22), док је са друге стране Јернеј Копитар у склопу своје катантанско-панонске теорије ипак посматрао хрватски кајкавски као део словеначког дијасистема (2006: 29), а исто то су, сматра М. Зајц, тврдили и словеначки филолози Франц Миклошич и Матија Мурко, не одузимајући при томе политичко право хрватским кајкавцима да себе именују Хрватима (2006: 219-221). Самим тим се може назрети да је питање односа кајкавског наречја и његове припадности хрватском 
или словеначком језичком дијасистему код утемељивача словенске филологије изазивало различита и често опречна мишљења.

Сам Александар Белић се у више својих чланака дотакао овога питања и изложио своје научно утемељено мишљење. Наиме, у расправи „О српском језику“, објављеној 1901. године, српски лингвиста посвећује пажњу дијалектима и наречјима српског (или хрватског) језика, у које убраја штокавско и чакавско. Са друге стране, уз кајкавски додаје одреднице „Погранични“" и „прелазни“, сматрајући га словеначким дијалектом, стога оно што је у њему „српско представља наносни слој, који није тешко одвојити од онога што је основно, а што се слаже са другим словеначким дијалектима посредно или непосредно“ (Белић 1901: 124). Дакле, у првој фази свог научног бављења словенским језицима Белић се приклања становишту словеначких лингвиста, који га припајају словеначком језику. Међутим, то је становиште од којег ће Белић направити отклон у својим наредним фазама рада, где ће више научне пажње посветити овоме питању.

Наиме, у чланку објављеном 1925. године у Даничићевом зборнику под насловом „Језичко јединство Срба, Хрвата и Словенаца код Ђуре Даничића и његових савременика“, аутор се, између осталог осврће и на проблематику кајкавског наречја. Белић се на овом месту прегледно осврће на проблем језичког јединства код знаменитих филолога који су деловали у Даничићево време. Испрва се фокусира на погледе Павла Јосифа Шафарика, те критикује његово виђење кајкавског питања. Наиме, „хрватски кајкавски диалекат сматрао је Шафарик хрватским наречјем (иако се оно у ранијим књигама назива 'словенским'), а словеначко-крањски (или словеначко-корушки) - словеначким наречјем, за које је сматрао да је блиско — хрватском“ (Белић 1998: 394). Белић се са Шафариком у некој мери слаже у вези са одређеним питањима, попут питања блискости чакавскога и штокавскога „диалекта“ те о сродности хрватског кајкавског са словеначким. Међутим, проблематичним, и за тадашње услове неприхватљивим, чини му се што је „Шафарик био спремнији да словеначки диалекат назове хрватским и обрнуто“" (Белић 1998: 394). Из наведеног произилази да је Белић свестан сродности словеначкога језика и хрватског кајкавског наречја, али да сматра да та два није могуће изједначити и о њима говорити као о једном целовитом језику. На том месту постаје видљив развој Белићеве мисли о овом изванредно сложеном питању.

Касније Белић износи и схватања Вука Стефановића Караџића, те се посвећује развоју његових идеја кроз различите етапе Вуковог филолошког рада. Тако наводи одломак из Вуковог писма из 1845. године, у којем Вук тврди да Крањци пак заносе на прави хрватски или крањски језик, те Белић на основу тога закључује да је Вуково схватање овде веома блиско Шафариковом (Белић 1998: 397). Само три године након тога Вук ће записати да је кајкавски врста словеначког, што Белић разу- 
ме као Вуково приклањање Миклошичевом становишту, те да је то засебан говор који се тек приближио српском током свога развоја (Белић 1998: 398). Затим се фокусира на Вукове ставове изнете у есеју „Срби сви и свуда“" у Ковчежићу 1849. године, где Вук наставља своју аргументацију оформљену под утицајем Миклошича према којој „,[м]еђу Словенце иду и данашњи Хрвати у вармеђи загрепској, вараждинској и крижевачкој, којијех је језик као пријелаз из крањскога у српски“ (Караџић 1849). Међутим, Белић, у складу са природом сопствених истраживања, у овој студији много више пажње посвећује питању односа чакавског и штокавског наречја у списима Вука Стефановића Караџића.

Након увида у Јагићев рад, Белић се посвећује Даничићевим погледима на односе унутар јужнословенског језичког дијасистема. Српски лингвиста на овом месту износи Даничићево схватање односа кајкавског наречја и словеначког језика, за које сматра да је трезвено и да се не може опорећи, а то је да ,је хрватски кајкавски диалекат по пореклу своме прелаз од словеначког ка српскохрватскоме“, те наводи да је Даничић „сасвим правилно и оштроумно, одвојио језичку страну питања од националне“ (Белић 1998: 412). Александар Белић на том месту експлицитно износи свој став у вези са хрватским кајкавцима, изграђен на основама Даничићевог схватања: „По националној страни они су Хрвати, а по језичкој — њихов језик, да се изразимо савременије, чини прелаз од онога језика којим данас говоре Словенци ка језику Срба и Хрвата“" (Белић 1998: 412). Из овог примера се може закључити да је Александар Белић већ 1925. године имплицитно свестан разлике између концепта језика којим говори одређени народ или његов део и језика једног народа који је према његовом етнониму именован. Односно, може се приметити да Белић има осећај за концепте који ће заживети са оснивањем социолингвистике као гране науке о језику. Са друге стране, Белићево разликовање језика којим говоре Словенци и језика Срба и Хрвата уноси одређену дискрепанцију између његовог схватања и формалног, те законског одређења језика Краљевине Срба, Хрвата и Словенаца као српско-хрватско-словеначког.

Поред тога, Белић у чланку објављеном године 1921. на француском језику, а на српском језику објављеном три године касније под насловом „Узајамни односи међу српскохрватским и словеначким језиком“, показује другачије тежње и ставове. Наиме, на овом месту он разликује словеначки језик, односно словеначки кајкавски дијалекат, од онога што назива хрватским кајкавским дијалектом. Наиме, Белић разуме кајкавску „дијалекатску нијансу“ као један део пређашњег заједничког језика Срба, Хрвата и Словенаца, те развој хрватске кајкавске варијанте објашњава снажним утицајем штокавштине на хрватске кајкавце (Белић 1999: 240-243).

Врхунац Белићевог бављења кајкавским наречјем јесте његов рад који је објављен у виду енциклопедијске одреднице „Кајкавски дијале- 
кат“у у оквиру друге књиге Нароgне енциклойедије срйско-хрвайско-словеначке из 1928. године. У овој одредници Белић износи своје целовито разумевање граница између словеначког језика и кајкавског дијалекта:

$<. .>$ и нема никакве сумње, да се К. Д., у извесном свом делу, находи у сродничким везама са словеначким језиком; али то још не значи да се К. Д. у данашњем своме саставу може сматрати словеначким дијалектом. Напротив. И ако се све до 18. века, па каткада и доцније, К. Д. назива и „словенским“, тај назив треба разумети исто онако као и назив „словински“ у Далмацији, као остатак од старог назива „словенски“ за све Јужне Словене, који су доцније потискивали национално-државни називи „српски“ и „хрватски“ у различним деловима наше територије, а не као „словеначки“ (Белић 1928: 210).

На овом месту Белић признаје лингвистичку повезаност између словеначког језика и кајкавског наречја, али затим наводи да се кајкавски не може сматрати делом словеначког језичког дијасистема. Ту тврдњу, између осталог, поткрепљује и разумевањем да се назив „словенски“ не односи на етноним Словенаца, већ на ширу идентитетску одредницу Јужних Словена. Међутим, потребно је истаћи да Белић на овом месту не аргументује своју тврдњу о паралели одреднице „словенски“ и „словински“".

Да је Белић остао доследан својим схватањима о односу словеначког језика и кајкавског дијалекта сведочи и његов критички приказ књиге Крайка ист̄орија словеначког̄ језика (Kratka zgodovina slovenskega jezika) Франа Рамовша ${ }^{3}$. Наиме, Белић је на овом месту изразио жаљење што се недовољно пажње посвећује развитку „кајкавског хрватског дијалекта који је потпуно ушао у састав српскохрватског језика“"(Белић 2000а: 169), истичући потребу да се са научног аспекта сагледа однос словеначког и кајкавског за време турских освајања, која су унеколико мењала дијалекатску и лингвистичку карту словеначког језика и свих трију наречја српскохрватскога, те на концу закључујући да су то питања „специфично српскохрватске дијалектологије“ (Исто). Посебно је битно и место на којем Белић записује овакав став — као критички осврт на моногра-

3 Као један од важних елемената проучавања односа између словеначке и српске науке о језику, али и српске и словеначке културе у међуратном периоду, издваја се богата и у великој мери сачувана кореспонденција коју су водили Александар Белић и Фран Рамовш. Ову кореспонденцију уредио је словеначки сербокроатиста Јанез Ротар, који ју је транскрибовао и издао под окриљем Словеначке академије наука и уметности 1990. године. Ово дописивање представља драгоцен траг о културним и академским приликама међуратне Југославије, али и након Другог светског рата, ако имамо у виду да је коресподенција између Франа Рамовша и Александра Белића трајала од 1920. године па све до Рамовшеве смрти, 1952. године. „Из кореспонденције са Рамовшем је очигледно у коликој мери је Белић подстицао словеначке лингвисте на писање, истраживање и уређивање библиографија“ (Đukanović 2019: 139), чиме се потврђује утицај Александра Белића и на језичке прилике у Словенији. 
фију о историји словеначког језика, где овакав Белићев став може звучати као додатно утврђивање како језичких граница тако и граница лингвистичког истраживања у вези са питањем кајкавског наречја.

\section{Белићеви погледи на словеначки језик у контексту уједињења југословенских народа}

„Уједињење у заједничку државу је била најзначајнија прекретница у историји Јужних Словена“ (Екмечић 1990: 832), a „ideja narodnog jedinstva, ideja postojanja/stvaranja jedinstvene jugoslovenske nacije, imala je višestruke koloseke i različite nosioce, svoje idealiste i pragmatičare, svoje pravovernike i jeretike, zatočnike i disidente, iskrene pobornike i konformiste" (Bešlin, Milošević 2017: 16-17). Стога што је југословенска идеја била тако разуђена и што су предлози за њено остваривање били доста различити, веома је важно обратити пажњу на све актере који су имали утицај на формирање Југославије. Иако је југословенска идеја бујала током деветнаестог века, за време Првог светског рата залагање за њу се наставило, и у неповољним условима постало снажније него икада (Wachtel 1998: 63).

Током Првог светског рата, поред оружаних сукоба, и даље су били вођени културни сукоби, па је тако, према М. Стевановићу (2018: 73), Александар Белић „поред неколико других истакнутих наших научних радника, био ангажован да се речју и пером бори за циљеве у одбрану којих је, и ради остварења којих је, његов народ оружјем водио тешке ратове“. Самим тим, истиче се важност културног рада у којем реномирани српски лингвиста добија прилику „да брани и образлаже ратне циљеве Србије <...> у које улази и захтев за уједињењем југословенских земаља дотад у саставу Аустро-Угарске, насељене Србима, Хрватима и Словенцима, са Краљевином Србијом у једну југословенску државну заједницу“" (Исто: 73-74).

Резултат те тежње опредмећен је у монографији под насловом $C p$ бија и јужнословенско йийање, објављеној у Нишу4 1915. године. У овој студији Белић је коришћењем интердисциплинарног приступа који је укључивао филолошке, лингвистичке, етнографске, антропогеографске и историјске методе настојао да „прикаже не само ово јединство српскохрватско-словеначког народа него и да тако, на посредан начин, научном интерпретацијом, потврди исправност и прогресивност оваквих народних тежњи за заједничком слободном државом“"(Стојанчевић 1991: 134). Важан аспекат југословенске идеје јесте идеја језичког јединства и блис-

4 Значајно је истаћи да је извод из ове студије, готово половина на овом месту објављеног текста, изашла исте године и у Њујорку под насловом Dokazi jugoslovenskoga jedinstva i povijest jugoslovenske misli od davnina do danas. Такав случај је пример праксе југословенске културне пропаганде, која је за време Првог светског рата свој фокус усмерила и према дијаспори и југословенским народима у емиграцији (Wachtel 1998: 63) 
кости словеначког језика са српскохрватским језиком, али и питање језичке политике унутар будуће државне заједнице троименог народа.

Александар Белић (1991: 21) на овом месту понавља своју тезу коју је изнео још 1901. године о несумњивој припадности кајкавског наречја словеначком језику, иако њиме говоре српскохрватски народи, чиме се успоставља континуитет његове мисли о овоме питању, што значи да 1915. године у његовом поимању кајкавског наречја још увек није дошло до преокрета у правцу ка српскохрватском. Још једно важно питање којем Белић посвећује своју научну пажњу јесте и питање јединства словеначког и српскохрватског језика. Наиме, истичући на више места да Словенци током илирског покрета упркос његовој снази нису примили српскохрватски језик, Белић (1991: 22, 118-119) тврди да су Словенци ипак пристајали уз унитаристичке покрете Јужних Словена, те да су у њима видели опстанак свога народа Међутим, важно је нагласити Белићево мишљење да ,је несумњиво да ће словеначки језик, и поред тога, још дуго времена живети у народу и имати свој развитак“(Исто: 22), што потврђује да током Првог светског рата Белић није сматрао да се од словеначког језика треба одустати, те да се залагао за вишејезичност и веровао у очување комуникативне функције словеначког језика барем у оквиру словеначког народа и његовог свакодневног живота. Такво схватање, са друге стране, може подразумевати и нарочит вид језичке хијерархизације, где се имплицитно исказује сумња у то да словеначки језик може да задовољи културне потребе словеначког народа, ако се има у виду да Белић тврди да је прихватање српскохрватског језика код Словенаца за Србе и Хрвате ствар од споредног значаја јер словеначки интелектуалци свакако добро владају српскохрватским језиком.

У том контексту Белић помиње и анкету часописа Bega о прихватању српскохрватског језика код Словенаца, па закључује:

Питање о књижевном језику словеначком унутрашње је питање словеначког народа; јер словеначки народ има несумњиво права да развија своје националне особине до крајњих граница; али је несумњиво за нас исто тако и то, да је словеначки народ везан са српскохрватским блиским и тесним везама некадашње заједнице и моћном везом хрватских кајкаваца, који данас чине нераздвојни део српскохрватског народа, иако по своме домаћем говору припадају словеначком језичком центру (Белић 1991: 23).

Самим тим, важно је имати у виду да Александар Белић у овом делу прокламује југословенско јединство које би се темељило на већем степену језичке аутономије, што је веома савремен поглед на мултиетничку и вишејезичку државну заједницу. Тиме исказује став о језичкој политици која не би смела да буде у знаку наметања српскохрватског језика као језика већинског становништва будуће државне заједнице, већ словеначком народу допушта право језичког самоопредељења. У датом контексту, имајући увид у ставове словеначких интелектуалаца и културних рад- 
ника који су своја становишта изнели у одговорима на Веgину анкету, Белић је морао бити свестан тога да словеначка интелектуална елита не би пристала на насилно наметање српскохрватског језика, иако је била готово сагласна у томе да развој словеначког језика у сваком случају треба усмерити у правцу српскохрватског језика.

У контексту уједињења потребно је посветити пажњу и Белићевом чланку објављеном у часопису Југ̄ославенска обнова - њива, који је био вођен у духу идеје интегралног југословенства („Hrvatska“ 2021). Наиме, Белићев чланак под насловом „О нашем национализму“ излазио је у наставцима током 1920. године и представља значајан документ у осветљавању културних тежњи у новоствореној Краљевини Срба, Хрвата и Словенаца. Белић се у првом делу чланка бави општим одређењима национализма и истиче његову важност, јер је „национализам извесног народа апстракција онога што се у њему у току историје вршило и што се спрема да се изврши“ (Белић 1920: 105). Из овога се може закључити да се у његовом чланку национализам још увек поима на традиционалан начин, који своје корене има у концепту националног бића из времена романтизма.

Други по реду наставак његовог чланка посвећен је словеначком питању и могућностима остваривања идеала скупне југословенске културе. Наиме, Белић је сасвим свестан да Словенци имају „свој књижевни језик и своју духовну аутономију <...> то је факат који се неда порећи“ (Белић 1920: 201). Такву чињеницу приписује специфичној ситуацији у којој се словеначка интелигенција налазила и наметањем немачког језика, према којем су интелектуалци развили отпор и још снажније утврдили положај и значај словеначког језика. Српски лингвиста у овом чланку есејистичког типа развија тезу о проширивању и уопштавању употребе српскохрватског језика у Словенији, који би „употребљаван и гајен од детинства $<$..> напоредо са словеначким, постао [би] друго моћно средство словеначке културе“" (Белић 1920: 202). У овом чланку Белић се залаже за снажно присуство српскохрватског језика у словеначком школству и јавној сфери до тренутка „када Словенци не буду били више подражаваоци у стилу и језику српско-хрватском, већ и самостални творци“" (Белић 1920: 202).

Другим речима, Белић подразумева да ће у једном тренутку ниво знања српскохрватског код словеначких говорника бити близу нивоа знања матерњег језика, афирмишући тиме став о плодотворној двојезичности унутар југословенског језичког и културног система. Томе у прилог говори и Белићев став о томе како ће и други крајеви Југославије осетити све разлоге за постојање словеначког језика када науче да цене његове творевине (Белић 1920: 203). У таквом становишту могу се открити елементи афирмације мултикултурализма, који подразумевају равноправност и једнако вредновање различитих културних, а у овом случају и језичких наноса унутар једне културе. 
Српски лингвиста затим додаје да је словеначки језик оправдан и да има права на живот, као и то да је словеначки језик средство за „непосредно и најинтимније исказивање свих прелива словеначке душе“ (Белић 1920: 202-203). Самим тим, о словеначком језику Белић говори са привилеговане позиције говорника српскохрватског језика али и једног од чинилаца креирања језичке политике, који валидира постојање и употребу словеначког језика, иако га такође имплицитно смешта у интимну сферу, постављајући га на нижи ниво у језичкој хијерархији. Томе у прилог иде и Белићева антитеза оваквој мултикултурној представи југословенске језичке ситуације:

$<\ldots>$ видимо подвојеност тамо где смо баш очекивали добру слогу и узајамност? Зар и сами Словенци, код којих се толико пута постављало питање о примању српско-хрватскога језика, не гоне и оне речи из свога језика које су нам их приближавале и уводе провинцијализме који их од заједнице још више отуђују. Некада су постојале тенденције да се словеначки језик потпуно приближи српско-хрватском језику и тако постепено изврши њихово уједињење итд. Зар баш данашња стварност не говори против онога што је написано овде, и зар нас баш она не принуђава да, апелујући на наше културно уједињење, скренемо пажњу Словеначкој јавности, куда се иде и куда ово води. <...> Ако својим недовољним учешћем у заједници овај или онај део слаби општи колективни рад, он ће још више слабити себе, када заједница њега не потпомогне (Белић 1920: 203).

Овакви искази омогућавају да се Белићева становишта о културном уједињењу сагледају и другачије. Они не показују сасвим афирмативан став према различитим језичким праксама, односно, другачијој језичкој политици која не би била усмерена према културним центрима тадашње државе, Београду и Загребу.

\section{Закључак}

Сличности словеначког језика и хрватског кајкавског наречја многе лингвисте су наводиле на потпуно оправдане закључке о њиховом заједничком пореклу, међутим однос између етничког идентитета и језика који га твори захтевао је да се језичке чињенице као такве у науци национално одреде. Самим тим, лингвистичка и филолошка истраживања имају априорни политички и идеолошки карактер. Зато је значајно испратити развој Белићеве мисли о односу словеначког и кајкавског, који почиње становиштем да је кајкавски део словеначког језичког дијасистема, али да представља прелазни појас према српскохрватском, чији елементи представљају наносни слој на словеначкој основи. Александар Белић у сличном кључу одређује однос кајкавског и словеначког у својим радовима до стварања Краљевине Срба, Хрвата и Словенаца, а затим се у његовој мисли о овоме питању може уочити фаза у којој се кајкавски 
именује као прелазни, али се не експлицира његова припадност словеначком језику. Последња фаза Белићевог схватања овога проблема представља експлицирање становишта о припадности кајкавског наречја српскохрватском језику, што остаје његов став до краја његове научне каријере, али и владајући став савремене науке о језику.

$\mathrm{Ca}$ друге стране, питање језичке политике у југословенским државним заједницама од Првог светског рата па до њиховог краја, обележено је многим проблемима. Упркос томе што је званични језик Краљевине Срба, Хрвата и Словенаца био српско-хрватско-словеначки, истина је да тај језички конструкт никада заправо није постојао, а статус словеначког језика био је сведен на употребу само на тлу словеначких земаља, док је другде био у употреби српскохрватски језик. Велику улогу у осветљавању тог проблема имају записи Александра Белића у вези са уједињењем југословенских народа. Његов став о словеначком језику није могуће једнозначно свести на подржавање или лингвистичку опресију, због тога што Белић са једне стране признаје словеначком језику право на коришћење, а са друге стране то право имплицитно ограничава на интимне потребе словеначког народа. Исто тако, Александар Белић сматра да словеначки језик треба да има сопствени развој, а са друге стране не гледа благонаклоно на тај развој уколико се он не креће у смеру постепеног зближавања са српскохрватским језиком. У таквим противречностима могу се уочити елементи језичке хијерархизације и тензије, зато што је српскохрватски услед бројности својих говорника и своје културне моћи надређен словеначком језику. Због тога Александар Белић као српски лингвиста може са своје привилеговане позиције критиковати словеначку језичку политику уколико се она не креће у правцу фаворизације српскохрватских или заједничких језичких елемената у словеначком језику.

На самом крају је илустративно навести и мисли српског лингвисте које одсликавају његов став о југословенској лингвистичкој ситуацији:

Сада се, још једном, можемо уверити колико су незгодни називи Србин, Хрват и Словенац за обележавање језичких разлика и колико је потребно свести их на друге називе. <..> Изједначење националних имена са диалектима значило би вештачко и нетачно цепање тих диалеката, а давање националних назива њиховим језичким јединицама у целини значило би произвољно протезање националних или политичко-националних назива на предмете који са њима не стоје у непосредној вези (Белић 1999: 244).

На овом месту значајно је истаћи да Александар Белић у потпуности разуме да национално одређење и ограничавање језичке реалности није и не може бити научно утемељено и да представља извор темељних методолошких неугодности. Упркос Белићевом ставу из 1918. године да „Словенце и Србо-Хрвате, покрећу иста жеља за уједињењем и исте националне аспирације и, следствено томе, њихова језичка граница 
не изазива никакве неспоразуме“ (Белић 2000б: 237), на крају се показало да је југословенска језичка ситуација извор многих како лингвистичких и културних тако и политичких неспоразума.

\section{ЛИТЕРАТУРА}

Белић Александар. „О српском језику“. Срйски књижевни глласник 3 (1901): 109-124.

Белић Александар. „О нашем национализму“. Југоословенска обнова-юива IV (1920): 105-107, 201-204, 297-300.

Белић Александар. „Franc Ramovš, Historična gramatika slovenskega jezika. II. Konsonantizem. V Ljubljani 1924“. Јужнословенски филолог̄ IV (1924): 239-244.

Белић Александар. „Кајкавски дијалекат“. Станојевић Станоје (ур.). Нароgна енцикло-

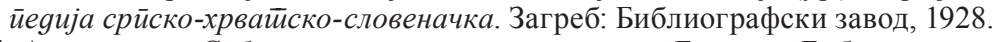

Белић Александар. Србија и јужнословенско йийање. Београд: Библиотека града Београда, 1991.

Белић Александар. „Језичко јединство Срба, Хрвата и Словенаца код Ђуре Даничића и његових савременика“. Белић Александар. О великим сйвараочима. Вук Кара-

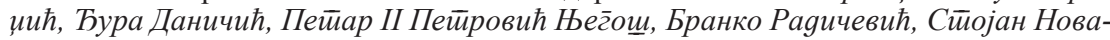
ковић, Љубомир Ст̄ојановић, прир. А. Младеновић. Београд: Завод за уџбенике и наставна средства, 1998.

Белић Александар. „Прилози историји словенских језика“. Белић Александар. Истиорија

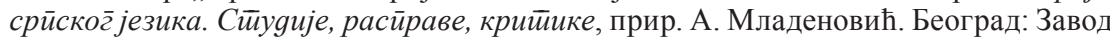
за уџбенике и наставна средства, 1999.

Белић Александар. „Fran Ramovš, Kratka zgodovina slovenskega jezika I. V Ljubljani, pri Akademski založbi, 1936, 246“. Белић Александар. Уйореgна словенска линг̄вистии$\kappa a / 2$, прир. Р. Јовићевић. Београд: Завод за уџбенике и наставна средства, 2000а.

Белић Александар. „Лингвистичка карта Балканског полуострва“. Белић Александар. O guјалекйима, прир. Д. Петровић. Београд: Завод за уџбенике и наставна средства, 2000б.

Екмечић Милорад. Сӣварање Југ̄ославије 1790-1918. 2. Београд: Просвета, 1989.

Караџић Вук. „Срби сви и свуда“. Ковчежић за истиорију, језик и обичаје Срба сва йри закона. Беч, 1849. <https://www.rastko.rs/filologija/vuk/vkaradzic-srbi_c.html> 21.02.2021.

Станојчевић Владимир. „Поговор“. Белић Александар. Србија и јужнословенско йийање. Београд: Библиотека града Београда, 1991.

Стевановић Михаило. „Живот и дело Александра Белића“. У: Алексанgар Белић (18781960). Београд: Међународни славистички центар, 2018.

Bešlin Milivoj. Milošević Srđan. „Multiperspektivnost (post)jugoslovenskih istorija“. Jugoslavija u istorijskoj perspektivi. Beograd: Helsinški odbor za ljudska prava u Srbiji, 2017: 15-25. <https://www.helsinki.org.rs/serbian/doc/jugoslavija\%20u\%20istorijskoj\%20 perspektivi.pdf $>21.02 .2021$.

Bulat Petar. „Pitanje jugoslovenskog književnog jezika i Slovenci“. Narodna odbrana, 1932.

Đukanović Maja. „Stoletje slovensko-srbskih literarnih stikov“. 1919 v slovenskem jeziku, literaturi in kulturi. Ljubljana: Znanstvena založba Filozofske fakultete, 2019: 135-141. $<$ https://centerslo.si/wp-content/uploads/2019/06/55-SSJLK_\%C4\%90ukanovic$\% \mathrm{CC} \% 81 . \mathrm{pdf}>23.02 .2021$.

„Hrvatska njiva“. Hrvatska enciklopedija, mrežno izdanje. Leksikografski zavod Miroslav Krleža, 2020. Pristupljeno 29. 1. 2021. http://www.enciklopedija.hr/Natuknica.aspx? $\mathrm{ID}=26411$

Leerssen Joep. „Notes towards a definition of Romantic Nationalism“. Romantik, 2(1) (2013): 9-35. <http://ojs.statsbiblioteket.dk/index.php/rom/article/view/20191/17807>

Liddicoat Anthony. „Tensions in the linguistic space“. Murray Neil, Scarino Angela (ed.), Dynamic Ecologies. Dordrecht: Springer, 2019: 217-227/ 
Novak Lukanovič Sonja. „Position of language: Case of the Slovene language“. Razprave in gradivo: revija za narodnostna vprašanja, 52 (2007): 186-197. <https://rig-td.si/en/ clanki/position-of-language-case-of-the-slovene-language-2/>12.02.2021.

Rešetar Milan. Odgovori na vprašanje o jugoslovanskem vprašanju. Veda III/ 4-5 (1913): 377-339.

Troch Pieter. „Between Tribes and Nation: The Definition of Yugoslav National Identity in Interwar Yugoslav Elementary School Curricula“. Südost-Forschungen, 69-70 (2010): 152-181. <https://core.ac.uk/download/pdf/55761401.pdf> 18.02.2021.

Wachtel Andrew. Making a Nation, Breaking a Nation: Literature and Cultural Politics in Yugoslavia. Stanford: Stanford University Press, 1998.

Wright Sue. Language Policy and Language Planning. London: Palgrave Macmillan, 2016.

Zajc Marko. Kje se slovensko neha in hrvaško začne. Ljubljana: Mondrijan, 2006.

\section{LITERATURE}

Belić Aleksandar. „O srpskom jeziku“. Srpski književni glasnik 3 (1901): 109-124.

Belić Aleksandar. „O našem nacionalizmu“. Jugoslovenska obnova-njiva IV (1920): 105-107, 201-204, 297-300.

Belić Aleksandar. „Franc Ramovš, Historična gramatika slovenskega jezika. II. Konsonantizem. V Ljubljani 1924“. Južnoslovenski filolog IV (1924): 239-244.

Belić Aleksandar. „Kajkavski dijalekat“. Stanojević Stanoje (ur.). Narodna enciklopedija srpsko-hrvatsko-slovenačka. Zagreb: Bibliografski zavod, 1928.

Belić Aleksandar. Srbija i južnoslovensko pitanje. Beograd: Biblioteka grada Beograda, 1991.

Belić Aleksandar. „Jezičko jedinstvo Srba, Hrvata i Slovenaca kod Đure Daničića i njegovih savremenika“. Belić Aleksandar. O velikim stvaraocima. Vuk Karadžić, Đura Daničić, Petar II Petrović Njegoš, Branko Radičević, Stojan Novaković, Ljubomir Stojanović, prir. A. Mladenović. Beograd: Zavod za udžbenike i nastavna sredstva, 1998.

Belić Aleksandar. „Prilozi istoriji slovenskih jezika“. Belić Aleksandar. Istorija srpskog jezika. Studije, rasprave, kritike, prir. A. Mladenović. Beograd: Zavod za udžbenike i nastavna sredstva, 1999.

Belić Aleksandar. „Fran Ramovš, Kratka zgodovina slovenskega jezika I. V Ljubljani, pri Akademski založbi, 1936, 246“. Belić Aleksandar. Uporedna slovenska lingvistika/2, prir. R. Jovićević. Beograd: Zavod za udžbenike i nastavna sredstva, 2000a.

Belić Aleksandar. „Lingvistička karta Balkanskog poluostrva“. Belić Aleksandar. O dijalektima, prir. D. Petrović. Beograd: Zavod za udžbenike i nastavna sredstva, 2000b.

Bešlin Milivoj. Milošević Srđan. „Multiperspektivnost (post)jugoslovenskih istorija“. Jugoslavija u istorijskoj perspektivi. Beograd: Helsinški odbor za ljudska prava u Srbiji, 2017: 15-25. <https://www.helsinki.org.rs/serbian/doc/jugoslavija\%20u\%20istorijskoj\%20 perspektivi.pdf $>21.02 .2021$.

Bulat Petar. „Pitanje jugoslovenskog književnog jezika i Slovenci“. Narodna odbrana, 1932.

Đukanović Maja. „Stoletje slovensko-srbskih literarnih stikov“. 1919 v slovenskem jeziku, literaturi in kulturi. Ljubljana: Znanstvena založba Filozofske fakultete, 2019: 135-141. $<\mathrm{https}: / / \mathrm{c}$ enters 1 o.si/wp-content/uploads/2019/06/55SSJLK \%C4\%90ukanovic\%CC\%81.pdf> 23.02.2021.

Ekmečić Milorad. Stvaranje Jugoslavije 1790-1918. 2. Beograd: Prosveta, 1989.

„Hrvatska njiva“. Hrvatska enciklopedija, mrežno izdanje. Leksikografski zavod Miroslav Krleža, 2020. Pristupljeno 29. 1. 2021. http://www.enciklopedija.hr/Natuknica. aspx?ID $=26411$

Karadžić Vuk. „Srbi svi i svuda“. Kovčežić za istoriju, jezik i običaje Srba sva tri zakona. Beč, 1849. <https://www.rastko.rs/filologija/vuk/vkaradzic-srbi_c.html> 21.02.2021.

Leerssen Joep. „Notes towards a definition of Romantic Nationalism“. Romantik, 2(1) (2013): 9-35. <http://ojs.statsbiblioteket.dk/index.php/rom/article/view/20191/17807>

Liddicoat Anthony. „Tensions in the linguistic space“. Murray Neil, Scarino Angela (ed.), Dynamic Ecologies. Dordrecht: Springer, 2019: 217-227/ 
Novak Lukanovič Sonja. „Position of language: Case of the Slovene language“. Razprave in gradivo: revija za narodnostna vprašanja, 52 (2007): 186-197. <https://rig-td.si/en/ clanki/position-of-language-case-of-the-slovene-language-2/> 12.02.2021.

Rešetar Milan. Odgovori na vprašanje o jugoslovanskem vprašanju. Veda III/4-5 (1913): $377-339$.

Stanojčević Vladimir. „Pogovor“. Belić Aleksandar. Srbija i južnoslovensko pitanje. Beograd: Biblioteka grada Beograda, 1991.

Stevanović Mihailo. „Život i delo Aleksandra Belića“. U: Aleksandar Belić (1878-1960). Beograd: Međunarodni slavistički centar, 2018.

Troch Pieter. „Between Tribes and Nation: The Definition of Yugoslav National Identity in Interwar Yugoslav Elementary School Curricula“. Südost-Forschungen, 69-70 (2010): 152-181. <https://core.ac.uk/download/pdf/55761401.pdf> 18.02.2021.

Wachtel Andrew. Making a Nation, Breaking a Nation: Literature and Cultural Politics in Yugoslavia. Stanford: Stanford University Press, 1998.

Wright Sue. Language Policy and Language Planning. London: Palgrave Macmillan, 2016.

Zajc Marko. Kje se slovensko neha in hrvaško začne. Ljubljana: Mondrijan, 2006.

\section{Darko Ilin}

\section{ALEKSANDAR BELIĆ'S VIEWS ON THE ISSUES OF SLOVENE LANGUAGE}

\section{Summary}

This paper analyzes the linguistic thought of Aleksandar Belić considering the issues of Slovene language in the Yugoslav context. Considering that Aleksandar Belić was a prominent figure in Serbian linguistics and in Yugoslav culture overall, being the head of the University of Belgrade and the president of the Serbian Royal Academy. For that reason it was possible to inspect Belić's works through the lens of language policy. This paper is comprised of who parts that approach the position of Slovene language in the Yugoslav context. The first one is the question of bordering and belonging of the Kajkavian regiolect, the main issue being whether the Kajkavian belongs to the Slovene or the Serbocroatian language diasystem. this part of the analysis examines the development and shifting of Belić's views on that matter. The second part is dedicated to inspecting the nuances in Belić's scientific and popular works regarding the Slovene language in the context of Yugoslav unification. Belic was one of the important cultural figures that contributed to the Yugoslav unification with his texts that addressed the topics of common Yugoslav cultural, literary and linguistic heritage. The nature of these texts allow for an in depth examination of Belićs views of the role of Slovene language and culture, therefore enabling us to draw important conclusions about this topic.

Key words: Slovene language, Aleksandar Belić, language policy, Kajkavian, Yugoslav unification. 